Supplement of Biogeosciences, 18, 2871-2890, 2021 https://doi.org/10.5194/bg-18-2871-2021-supplement (C) Author(s) 2021. CC BY 4.0 License.

(c) (1)

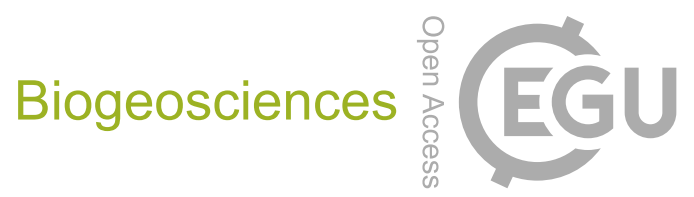

Supplement of

\title{
Coastal processes modify projections of some climate-driven stressors in the California Current System
}

\section{Samantha A. Siedlecki et al.}

Correspondence to: Samantha A. Siedlecki (samantha.siedlecki@uconn.edu)

The copyright of individual parts of the supplement might differ from the article licence. 


\begin{tabular}{|c|c|c|c|c|c|}
\hline & $\begin{array}{l}\text { A. } \\
\text { CCS } \\
(1 \\
\text { degree })\end{array}$ & $\begin{array}{l}\text { B. } \\
\text { CCS (12 } \\
\mathrm{km})\end{array}$ & $\begin{array}{l}\text { C. } \\
\text { N-CCS } \\
\text { (1 degree) }\end{array}$ & $\begin{array}{l}\text { D. } \\
\text { N-CCS } \\
(12 \mathrm{~km})\end{array}$ & $\begin{array}{l}\text { E. } \\
\text { N-CCS } \\
(1.5 \mathrm{~km})\end{array}$ \\
\hline TA surf & -20.41 & $\begin{array}{l}-7.88 \\
-5.88^{*}\end{array}$ & -26.01 & $\begin{array}{l}-7.40 \\
-6.29 *\end{array}$ & $\begin{array}{l}-7.46 \\
-10.53 *\end{array}$ \\
\hline TA $200 \mathrm{~m}$ & -8.90 & $\begin{array}{l}0.68 \\
-3.10 *\end{array}$ & -7.72 & $\begin{array}{l}1.91 \\
-1.0^{*}\end{array}$ & $\begin{array}{l}-3.05 \\
-8.22 *\end{array}$ \\
\hline TA bot & -10.38 & $\begin{array}{l}-0.03 \\
-1.90 *\end{array}$ & -7.70 & $\begin{array}{l}1.00 \\
0.28^{*}\end{array}$ & $\begin{array}{l}-1.66 \\
-4.17 *\end{array}$ \\
\hline DIC surf & 101.44 & $\begin{array}{l}93.32 \\
91.65^{*}\end{array}$ & 80.52 & $\begin{array}{l}89.93 \\
91.26^{*}\end{array}$ & $\begin{array}{l}80.98 \\
73.57 *\end{array}$ \\
\hline DIC 200m & 96.82 & $\begin{array}{l}103.24 \\
94.35^{*}\end{array}$ & 78.04 & $\begin{array}{l}89.49 \\
91.74 *\end{array}$ & \begin{tabular}{|l}
87.37 \\
$80.93 *$ \\
\end{tabular} \\
\hline DIC bot & 66.33 & $\begin{array}{l}75.25 \\
92.51^{*}\end{array}$ & 69.63 & $\begin{array}{l}79.92 \\
83.93 *\end{array}$ & \begin{tabular}{|l}
77.66 \\
$83.71 *$
\end{tabular} \\
\hline PO4 surf & -0.0561 & $\begin{array}{l}-0.0727 \\
-0.0754 *\end{array}$ & -0.0403 & $\begin{array}{l}-0.0732 \\
-0.0802 *\end{array}$ & $\mathrm{~N} / \mathrm{A}$ \\
\hline PO4 200m & 0.0655 & $\begin{array}{l}0.0273 \\
-0.0180 *\end{array}$ & 0.0191 & $\begin{array}{l}0.0337 \\
0.0062 *\end{array}$ & $\mathrm{~N} / \mathrm{A}$ \\
\hline PO4 bot & -0.0064 & $\begin{array}{l}0.0112 \\
0.0096^{*}\end{array}$ & 0.0131 & $\begin{array}{l}0.0397 \\
0.0342\end{array}$ & N/A \\
\hline NO3 surf & -0.3216 & $\begin{array}{l}-0.1869 \\
-0.2831 *\end{array}$ & -0.3449 & $\begin{array}{l}-0.3247 \\
-0.3678 *\end{array}$ & \\
\hline NO3 200m & 1.1383 & $\begin{array}{l}1.4705 \\
0.5535^{*}\end{array}$ & 0.8318 & $\begin{array}{l}1.2999 \\
0.8426^{*}\end{array}$ & \\
\hline NO3 bot & 0.6392 & $\begin{array}{l}0.6374 \\
0.7061 *\end{array}$ & 0.6833 & $\begin{array}{l}0.9136 \\
0.8799 *\end{array}$ & \\
\hline
\end{tabular}

Table S1: Annual average differences between climate stressor variables (all in $\mathbf{m m o l} / \mathrm{m3})$ in the future and the base/modern conditions for the 1 degree, $12-\mathrm{km}$, and $1.5-\mathrm{km}$ projections over different regions of the water column (200 $\mathrm{m}$ averaged, surface, and bottom $<500 \mathrm{~m}$ ). Column $A$ includes the global (1 degree) ensemble average difference for the CCS region followed by, in column $B$, the CCS wide difference from the $12 \mathrm{~km}$ downscaled results. The $N-C C S$ region results span columns $\mathrm{C}-\mathrm{E}$ in this table. The next three columns detail the differences in the Cascadia domain for the global ensemble average (column C), the 12-km (column D) and 1.5-km downscaled projections (column E). Within the downscaled simulation, values are also provided just on the shelf $(<200$ meter isobath) and denoted with an asterisk $(*)$ next to the number. 


\begin{tabular}{|c|c|c|c|}
\hline & $200 \mathrm{~m}$ avg & Surface & $\begin{array}{l}\text { Bottom } \\
(<500 \mathrm{~m})\end{array}$ \\
\hline$\Delta \mathrm{pCO}_{2}(\mu \mathrm{atm}) \& \Delta \mathrm{TA}$ & 0.94 & 0.19 & 0.92 \\
\hline$\Delta \mathrm{pCO}_{2}(\mu \mathrm{atm}) \& \Delta \mathrm{DIC}$ & 0.04 & 0.34 & 0.99 \\
\hline$\Delta \mathrm{pCO}_{2}(\mu \mathrm{atm}) \& \Delta \mathrm{NO}_{3}$ & 0.47 & 0.35 & 0.62 \\
\hline$\Delta \mathrm{pCO}_{2}(\mu \mathrm{atm}) \& \Delta \mathrm{T}$ & 0.01 & 0.81 & 0.36 \\
\hline$\Delta \mathrm{pH} \& \Delta \mathrm{TA}$ & 0.04 & 0.74 & $0.59, \mathrm{p}=0.20$ \\
\hline$\Delta \mathrm{pH} \& \Delta \mathrm{DIC}$ & 0.001 & 0.81 & 0.28 \\
\hline$\Delta \mathrm{pH} \& \Delta \mathrm{NO}_{3}$ & 0.03 & $0.56, p=0.3$ & 0.003 \\
\hline$\Delta \mathrm{pH} \& \Delta \mathrm{T}$ & 0.01 & -0.19 & 0.03 \\
\hline$\Delta \Omega \& \mathrm{TA}$ & 0.27 & -0.0009 & $0.66, p=0.21$ \\
\hline$\Delta \Omega \& \Delta \mathrm{DIC}$ & 0.25 & 0.99 & 0.71 \\
\hline$\Delta \Omega \& \mathrm{NO}_{3}$ & 0.0002 & 0.14 & 0.95 \\
\hline$\Delta \Omega \& \mathrm{~T}$ & 0.24 & 0.22 & 0.002 \\
\hline
\end{tabular}

Table S2: We examine the relationship between the carbon variables that are modified in the downscaled simulations and the other variables representative of different processes. The $R^{2}$ between the anomalies in Column C from Table 1 and either another variable within the same depth region in Table 1 or column $B$ from Table S1 with values $>0.5$ highlighted in grey. For example for the correlations between $\mathrm{pCO}_{2}$ and TA over the $200 \mathrm{~m}$ avg, the correlations are between the $\triangle \mathrm{pCO} 2$ in the $200 \mathrm{~m}$ avg section from Table 1 for the entire CCS region (column C) from the downscaled models and the TA from column B from Table S1 for the $200 \mathrm{~m}$ row. All $p$ values were less than 0.05 indicating significant correlations. 


\section{(a)}

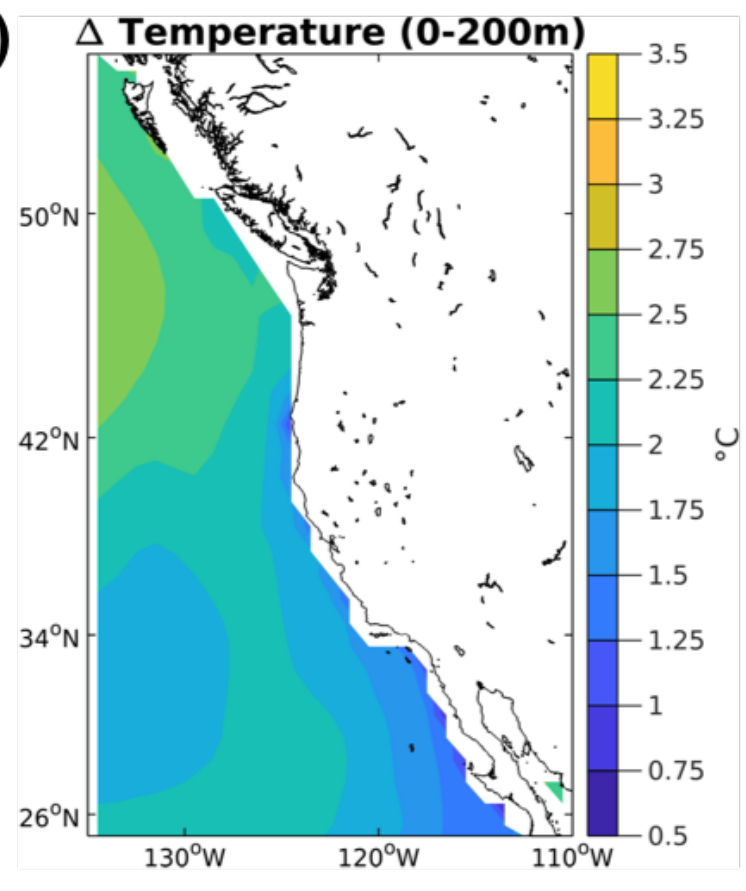

(c)

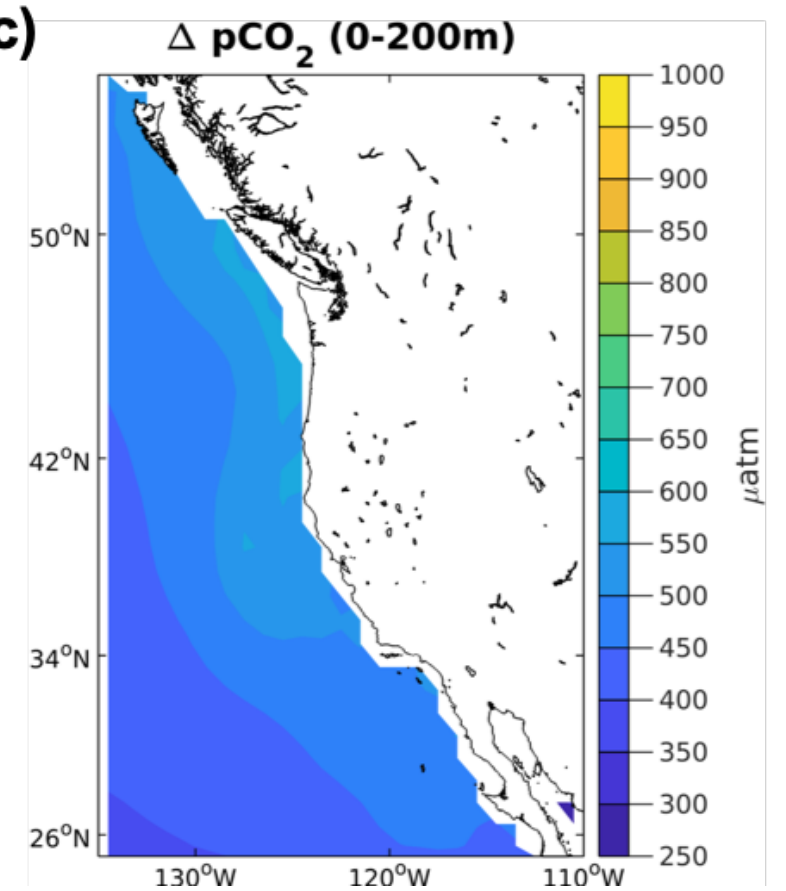

(b)

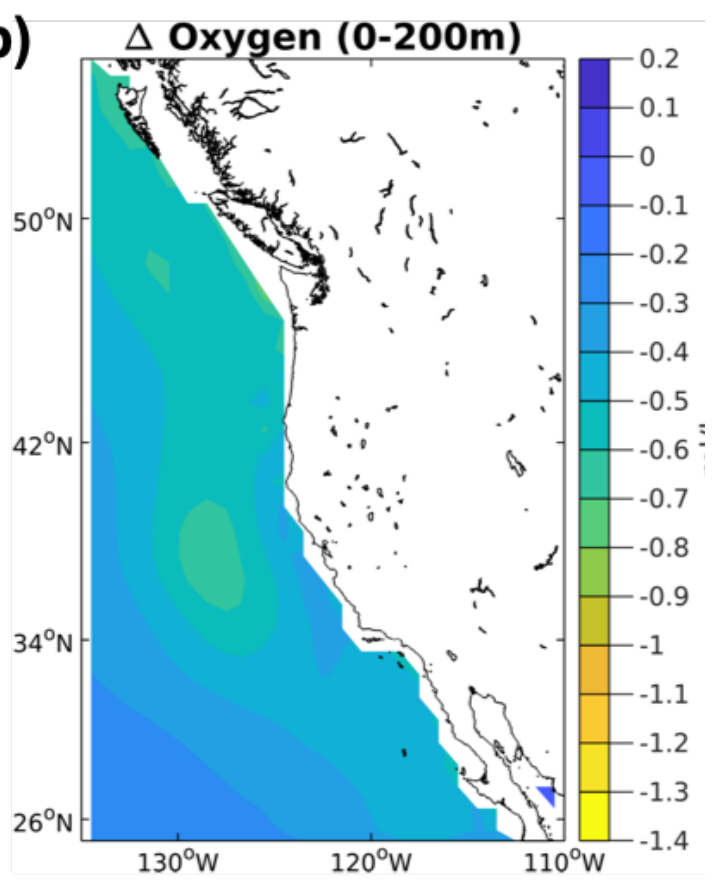

(d)

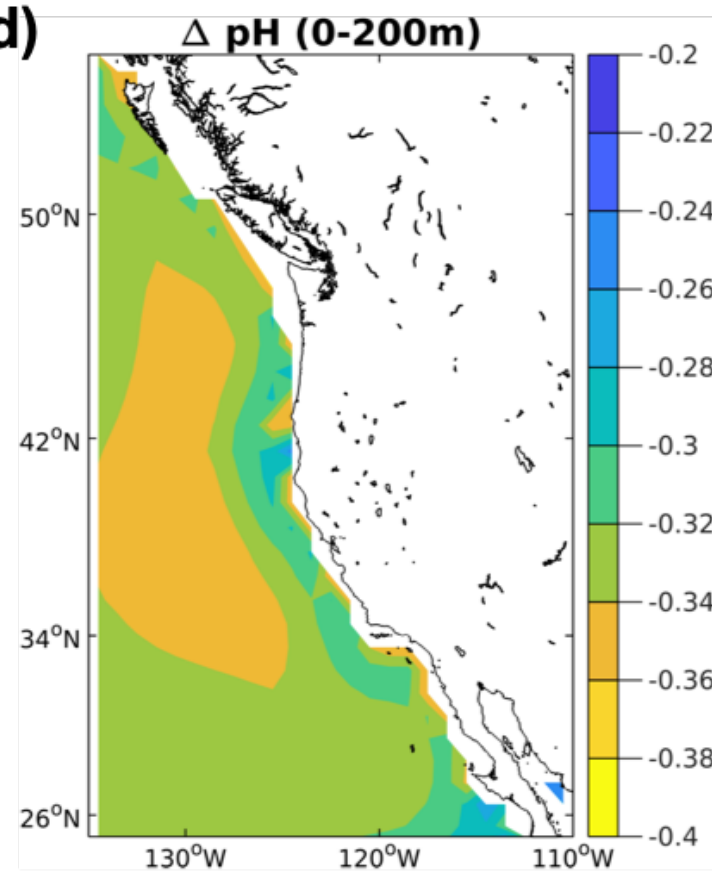

Figure S1. Global changes from the CMIP5 ensemble average for the CCS region - future minus base conditions (a) temperature $(\operatorname{deg} \mathrm{C})(\mathrm{b}) \mathrm{O}_{2}(\mathrm{ml} / \mathrm{l})(\mathrm{c}) \mathrm{pCO}_{2}(\mu \mathrm{atm})(\mathrm{d}) \mathrm{pH}$. 


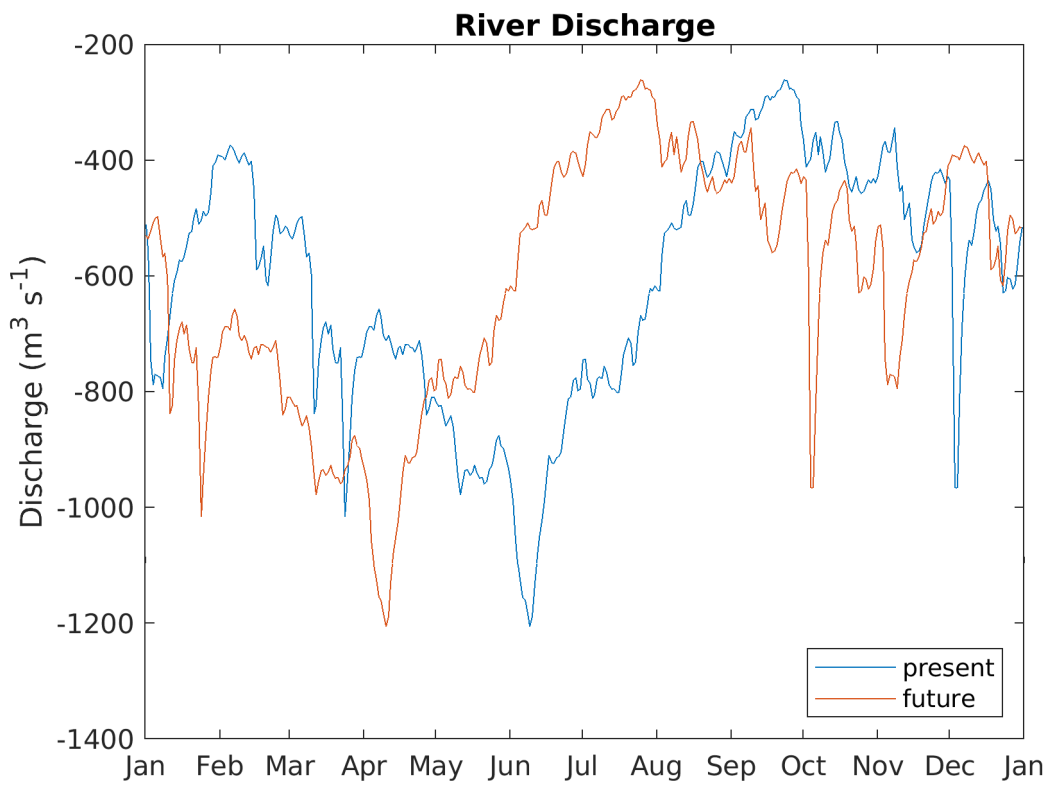

Figure S2. Freshwater discharge forcing for the $1.5 \mathrm{~km}$ simulation in the present and future simulations as described in the methods. 